\title{
U-Pb zircon age of the Krásné Loučky tuffite: the dating of Visean flysch in the Moravo-Silesian Paleozoic Basin (Rhenohercynian Zone, Czech Republic)
}

\author{
Jakub JIRÁSEK ${ }^{1, *}$, Jiří WLOSOK ${ }^{1}$, Martin SIVEK ${ }^{1}$, Dalibor MATÝSEK ${ }^{1}$, Mark SCHMITZ², \\ Ivana SÝKOROVÁ ${ }^{3}$ and Zdeněk VAŠíČEK ${ }^{4}$
}

1 VŠB - Technical University of Ostrava, Faculty of Mining and Geology, 17 listopadu 15/2172, 70833 Ostrava-Poruba, Czech Republic

2 Boise State University, Department of Geosciences, 1910 University Drive, Boise, ID, U.S.A.

3 Academy of Sciences of the Czech Republic, Institute of Rock Structure and Mechanics, V Holešovičkách 41, 18209 Praha 8, Czech Republic

4 Academy of Sciences of the Czech Republic, Institute of Geonics, Studentská 1768, 70800 Ostrava-Poruba, Czech Republic

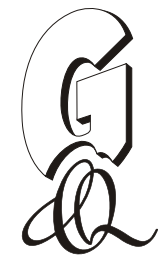

\begin{abstract}
Jirásek, J., Wlosok, J., Sivek, M., Matýsek, D., Schmitz, M., Sýkorová, I., Vašíček, Z., 2014. U-Pb zircon age of the Krásné Loučky tuffite: the dating of Visean flysch in the Moravo-Silesian Paleozoic Basin (Rhenohercynian Zone, Czech Republic). Geological Quarterly, 58 (4): 659-672, doi: 10.7306/gq.1201

The only previous U-Pb zircon date for the the Early Carboniferous flysch sequence of the Moravo-Silesian Paleozoic Basin was published in 1987 from tuffogenic material from Kobylí Quarry at Krásné Loučky near the town of Krnov (Silesia, Czech Republic). The measured age of 319 Ma did not agree with its stratigraphic position, and was used as the basis for a hypothesized block of Late Carboniferous paralic molasse incorporated during a later tectonic event. During a survey of the still-active quarry in 2010, volcaniclastic horizons were identified and sampled. Direct correspondence of the tuff units to those sampled in 1987 cannot be proved but is likely. High precision chemical abrasion - thermal ionization mass spectrometry (CA-TIMS) U-Pb dating of zircon from this new material has yielded an age of $340.05 \pm 0.22 \mathrm{Ma}$, which correlates to the previously inferred stratigraphic age of the locality and the current calibration of the Early Carboniferous geologic time scale. The newly established age corresponds to the Visean stage and dates the boundary between the Horní Benešov and Moravice formations that can be correlated with other foredeep basins of the Culm in the European Variscides. A population of detrital Cambro-Ordovician zircons and a single $2.0 \mathrm{Ga}$ old zircon crystal from the same volcaniclastic layer dated by laser ablation inductively coupled plasma mass spectrometry (LA-ICPMS) are consistent with the known age of source material in the Variscan orogenic front.
\end{abstract}

Key words: volcaniclastic sediment, Horní Benešov Formation, Variscan foreland, Visean, Carboniferous, chronostratigraphy.

\section{INTRODUCTION}

The stratigraphy of the flysch deposits of the Culm in the Early Carboniferous of the Moravo-Silesian Paleozoic Basin contains many unsolved problems. This is mainly due to its uniform lithology and lack of biostratigraphically important fossils. There is ongoing debate about the age and relationships of its lithostratigraphical units. This discussion may be solved (at least partly) by radiometric dating, but so far, the only available absolute age is that reported in an unreviewed publication (Přichystal, 1987). The published isotope dilution - thermal ionization mass spectrometry (ID-TIMS) U-Pb zircon age of

\footnotetext{
* Corresponding author, e-mail: jakub.jirasek@vsb.cz
}

Received: April 15, 2014, accepted: June 25, 2014; first published online: November 14, 2014
$319 \mathrm{Ma}$ for the volcaniclastic horizon exposed in Kobyli Quarry at Krásné Loučky near the town of Krnov was problematic for various reasons (not being consistent with either local lithology or biostratigraphy) documented below. Nevertheless, this age has been quoted in a number of later studies dealing with the Moravian-Silesian Culm (e.g., Přichystal, 1993; Hladil and Dvořák, 1994; Cháb, 2010).

"Two decimetre-thick layers of weathered crystalloclastic tuff' from an unspecified location are mentioned in the unpublished explanatory notes that accompany the geological base map at 1:25,000 scale, sheet 15-134 Brantice (Maštera and Otava in Otava, 1984). This date for these rocks was also reported by Prichystal (1987), but further details of the locality were not given. It was mentioned that one of these layers had been quarried out in 1985. Príichystal (1987) also mentioned spores which should have confirmed a Late Carboniferous age, but gave no more information. Karkusz (1989) stated that this layer of "crystal tuff" had been quarried out, and described at least one other tuffaceous layer that was very similar to the orig- 
inal horizon. However, he found no evidence for a Late Carboniferous age of any tuffaceous beds in the quarry. Several attempts were made after 1990 by geologists under the leadership of $O$. Kumpera to locate the layers of volcaniclastic material in the quarry, but these were not successful, nor did they find any rock or palaeontological material with an age corresponding to the Late Carboniferous. Palaeontological revision of flora found in the quarry (Purkyňová, 2003) did not confirm any occurrence of Late Carboniferous species. Přichystal, Hladil, Kuovo, Otava and Valterová in Weyer and Menning (2006) again published the original information and radiometric age without any further details of the site. The latter authors are also vague regarding the palynological evidence for a Namurian A age - no single taxon is identified and no relevant photographs are given. They refer only to an unpublished manuscript by Otava and Valterová (1992, in Weyer and Menning, 2006).

In 2010, during a survey of the still-active quarry, we discovered layers of volcaniclastic sediment (tuffite) which are macroscopically and microscopically very similar to the originally described exposures. Here we report a newly determined high-resolution CA-TIMS U-Pb zircon-based age of deposition for one of these layers which is compatible with the geological setting and structure of the quarry and its surroundings. In this study, we present a number of arguments in support of the accuracy of this new age (e.g., geological setting and degree of metamorphic transformation).

\section{GEOLOGICAL SETTING}

\section{MORAVO-SILESIAN PALEOZOIC BASIN}

According to Unrug (1966) and Unrug and Dembowski (1971), the Moravo-Silesian Paleozoic Basin was formed in the eastern domain of the Central European Variscides. It was developed in the foreland of the Variscan orogen and became part of its outer zones, the so-called Rhenohercynicum and Subvariscicum (Schulmann and Gayer, 2000; Schulmann et al., 2009).

The basin is filled by some of the younger deposits overlying Brunovistulicum (Buła and Żaba, 2005; Kalvoda et al., 2008). Devonian sedimentation started with pre-flysch carbonates (Bábek et al., 2007) and continued into the marine clastic sediments of the Carboniferous flysch (Kumpera, 1983; Dvořák, 1994). This so-called Culm facies provides indirect evidence of syn-orogenic sedimentation during the Variscan orogeny from possibly as early as the Tournaisian through the whole of the Visean to the lowermost Serpukhovian (Bábek et al., 2007; Jirásek et al., 2013a). The final stages are marked by deposition of the coal-bearing paralic and terrigenous molasse of the Upper Silesian Basin. The basin fill is overlain mostly by Neogene and Quaternary sedimentary sequences and, in the eastern part of the basin, also by Neogene deposits of the Carpathian Foredeep and, further to the south-east, by the nappes of the Outer Western Carpathians (Late Jurassic to Paleogene).

In the Czech Republic, the Early Carboniferous flysch sequence is exposed in the Drahany Upland, the Oderské vrchy Mts., and the Nízký Jeseník Mts. (e.g., Patteisky, 1929; Kumpera, 1983; Dvořák, 1994), and in Poland west of the Upper Silesian Basin and east of the town of Głuchołazy (Trzepier- czyńska, 2003). It is composed of four major lithostratigraphic units: the Andělská Hora Fm., the Horní Benešov Fm., the Moravice Fm., and the Hradec-Kyjovice Fm. (Fig. 1). Their total thickness probably reaches 7.5 to $12 \mathrm{~km}$ (Kumpera and Martinec, 1995; Mazur et al., 2006), but precise thicknesses cannot be given because of strong tectonic reworking in the Variscan accretionary wedge (Grygar and Vavro, 1995; Kumpera and Martinec, 1995), as well as intense post-Carboniferous and probably also Carboniferous erosion in those parts close to the orogenic front (Francu et al., 2002). Only limited information has been obtained from a few boreholes.

The types of strata filling the basin, together with their thickness and extent, vary both stratigraphically and spatially. Generally, in the Andělská Hora Fm., the coarse-grained deposits (conglomerates, greywackes) are as abundant as are siltstones and clayey shales. In the Horní Benešov Fm. greywackes predominate. In the Moravice Fm. and Hradec-Kyjovice Fm. (with the exception of the Hradec Member) the proportion of siltstones and clayey shales is greater and the deposits are more mature so sandstones are more abundant than greywackes (Kumpera, 1974, 1976; Kukal, 1980; Dvořák, 1994). Kumpera and Martinec (1995) concluded that sedimentation was driven by multiple geotectonic events in the foreland basin. Mostly deep-water siliciclastic turbidites were deposited on an elongate submarine fan, although shallow-water strata are also present. Cyclicity in the sedimentary sequence was also recognized by Skoček (1989) and Bábek et al. (2004). The intensity of the diagenetic overprint decreases upwards in the stratigraphic sequence i.e., from the west to the east. In the Hradec-Kyjovice Formation the vitrinite reflectance $R_{0}$ is mostly between 5.5 to $2.0 \%$ (authors' unpubl. data); in the Ostrava Formation values of $R_{o}$ in the range 2.0 to $0.5 \%$ were reported by Sivek et al. (2003) and Kandarachevová et al. (2009).

Biostratigraphic information on the Culm strata of the Moravian-Silesian Basin varies considerably. The stratigraphically higher units (the Moravice and Hradec-Kyjovice formations) are known to contain a locally rich fauna, especially bivalves and goniatites, and flora including both macroflora and spores. According to Kumpera (1996), fossil remains in the stratigraphically lower units (the Andělská Hora and Horní Benešov formations) are very rare and because of the higher grade of metamorphism they are not very well-preserved, so they are of little use for biostratigraphic correlation. The lack of biostratigraphic information does not preclude the idea that the flysch zone in the Nízký Jeseník Mts. consists of two internally imbricated nappes and that the Andělská Hora and Horní Benešov formations are stratigraphic equivalents of the Moravice and Hradec-Kyjovice formations (e.g., Cháb, 2010; and counter-arguments by Dvořák, 1986). In this study, however, we adopt the lithostratigraphic division of the Culm in the Nízký Jeseník Mts. proposed by Zapletal et al. (1989). This is the result of systematic work by three most distinguished post-World War II investigators of this area and is widely accepted. The zonation of heavy minerals in the flysch strata described by Hartley and Otava (2001) also supports this division of the stratigraphy. The Moravice Formation is classified as belonging to goniatite zones $\mathrm{Go}_{2-3}$ to Go $\beta_{\mathrm{mu}}$ (Kumpera, 1983). In terms of the content of heavy minerals, the lower part of the Moravice Formation belongs to the Lower Heavy Mineral Zone, and the middle belongs to the Middle Heavy Mineral Zone, while the upper section ranges up to the bottom of the Upper Heavy Mineral Zone (Hartley and Otava, 2001). 


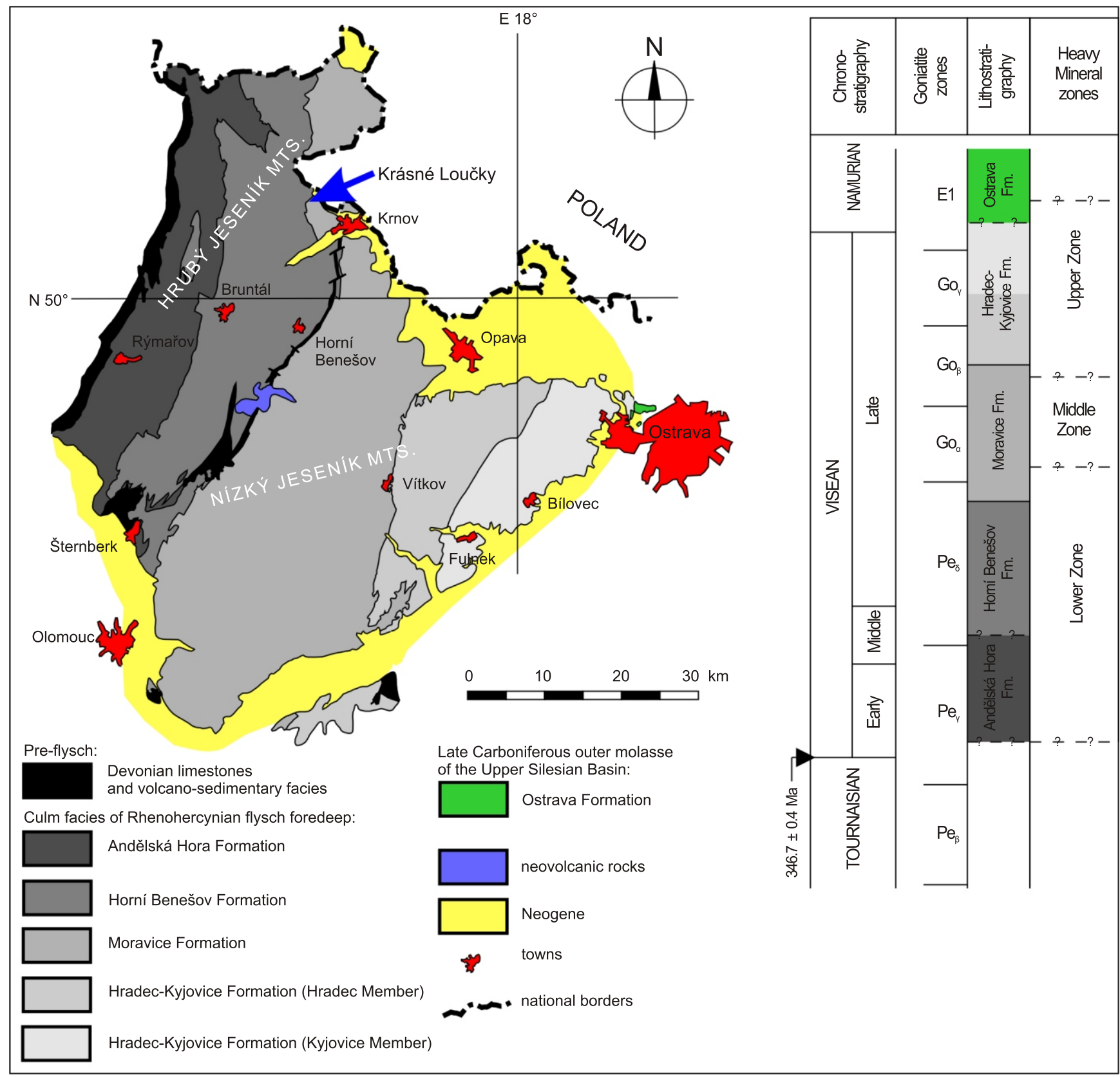

Fig. 1. Simplified geological map of the Nízký Jeseník part of the Moravo-Silesian Paleozoic Basin (modified from Dvořák, 1994) with stratigraphic column and goniatite zonation (after Kumpera, 1983, modified) and Heavy Mineral zones (Hartley and Otava, 2001)

\section{KRÁSNÉ LOUČKY - KOBYLÍ QUARRY}

The locality Krásné Loučky - Kobylí, where the dated volcaniclastic horizon is exposed, is the operating quarry owned by KAMENOLOMY ČR s.r.o./Ltd. It lies on the northwestern slope of Kobylí Hill, approximately $1 \mathrm{~km}$ south-west of the village of Krásné Loučky, a suburb of the town of Krnov, about $50 \mathrm{~km}$ north-west of the city of Ostrava (coordinates Lat. N 507'13.08”' Long. E 017³7'40.30").

The flysch sequence, consisting mainly of coarse flysch with lesser amounts of rhythmic flysch and shale, is permanently quarried (Novák and Horák, 1981). These strata belong to the Brantice Member of the Horní Benešov Formation near the transition to the pelite-dominated Moravice Formation (Kumpera, 1961; Kumpera and Vašíček, 1961). The whole area has been strongly affected by tectonism (Kumpera, 1966). In detail, the complex structure of the Kobyli greywacke deposit results in significant variations in facies in both horizontal and vertical directions (Karkusz, 1989).

The first fossils from Kobylí Quarry were described by Kumpera (1961), who found a layer rich in fragments of Asterocalamites cf. scrobiculatus (Schlotheim). The same species was also found at several sites nearby (Patteisky, 1929; Kumpera, 1966). Karkusz (1989) refers to the discovery of fossil-bearing, grey-black, micro-biodetrital limestone containing the foraminifera Globoendothyra sp., Eostaffella sp., Archaediscus krestovnikovi Rauser, Archaediscus sp., Endothyra sp., Palaeotextulariidae indet., and the algae Calcisphaera sp. and Stacheiinae indet. This layer is described as a slipped block with an age in the range from the upper Mid- 
dle to Late Visean. Purkyňová (2003) published a new assessment of palaeobotanical material collected from the quarry. In addition to finds of Asterocalamites scrobiculatus (Schloth.), abundant fragments of the tree-like lycopodiophyta Lepidodendron lossenii Weiss, together with rarer Lepidodendron volkmannianum Sternberg and Knorria sp. and also probably the pteridosperms Sphenopteris (?Rhodeopteridium Sphenopteridium) sp. ind. and ?Fryopsis sp. were identified. Purkynnová (2003) therefore interpreted the plant thanatocoenosis as being of Early Carboniferous age without younger floral elements. In terms of the occurrence of heavy minerals (Karkusz, 1989) and their utilization for local stratigraphy (Hartley and Otava, 2001), the quarry lies in the Lower and at the transition to the Middle Heavy Mineral Zone (Fig. 1).

Low-temperature hydrothermal mineralisation occurs in fissures and tectonically disturbed zones in the quarry and was described by Zimák et al. (2002). The mineral assemblage consists of calcite, quartz, limonite, pyrite (Krut'a, 1954-1955), barite, galena (Krut'a, 1963), chalcopyrite, malachite, stilpnosiderite (Krut'a, 1973) and chlorite (Zimák et al., 2002).

\section{CONTROVERSIAL DATING AND SUPPORTING EVIDENCE}

Tuffaceous horizons in the quarry at Krásné Loučky Kobyli were first described by Otava (1984). Two approximately decimetre-thick layers were identified, but no further details were given. Zircons were separated from these tuffaceous layers and subsequently dated in the Isotope Geology Department at the Geological Survey of Finland and the results were published by Prichystal (1987). The ID-TIMS method (Krogh, 1973) was employed using the decay constants published by Steiger and Jäger (1977). According to the author, three entirely concordant ages were determined: ${ }^{238} \mathrm{U} /{ }^{206} \mathrm{~Pb}: 319 \pm 2 \mathrm{Ma}$, ${ }^{235} \mathrm{U} /{ }^{207} \mathrm{~Pb}: 319 \pm 3 \mathrm{Ma}$ and ${ }^{207} \mathrm{~Pb} /{ }^{206} \mathrm{~Pb}: 319 \pm 21 \mathrm{Ma}$. Furthermore, it was stated that "in the vicinity of the investigated tuff, J. Otava collected samples of coal material from which spores of Namurian age were extracted (pers. comm. from J. Otava, identification by P. Valterová)". Karkusz (1989 stated that the site of the original dated tuff had been quarried out. He also mentioned the occurrence of an unspecified number of other tuffites, often containing plant detritus. Subsequently, an identical report on the dating of the tuff at $319( \pm 2,3,21)$ Ma was published by Prichystal et al. (in Weyer and Menning, 2006).

\section{MATERIALS AND METHODS}

Dozens of samples of tuffite and nearby organic-rich shale were obtained from the quarry. They were used for zircon separation and dating, mineralogical and petrological analysis (tuffite) and for the search for palynological material and organic matter analysis (shale).

Zircon crystals were separated from the tuffite by conventional density and magnetic methods. The entire zircon separate was placed in a muffle furnace at $900^{\circ} \mathrm{C}$ for 60 hours in quartz beakers to anneal minor radiation damage; annealing enhances cathodoluminescence (CL) emission, promotes more reproducible interelement fractionation during laser ablation inductively coupled plasma mass spectrometry (LA-ICPMS), and prepares the crystals for subsequent chemical abrasion (Mattinson, 2005). Following annealing, individual grains were hand-picked and mounted, polished and imaged by cathodoluminence $(\mathrm{CL})$ on a scanning electron microscope. From these compiled images, the locations of spot analyses for LA-ICPMS were selected.
$\mathrm{U}-\mathrm{Pb}$ isotope systematics and trace element compositions were analysed by LA-ICPMS using a ThermoElectron X-Series II quadrupole ICPMS and New Wave Research UP-213 Nd: YAG UN $(213 \mathrm{~nm})$ laser ablation system. In-house analytical protocols, standard materials, and data reduction software were used for simultaneous acquisition and real-time calibration of $\mathrm{U}-\mathrm{Pb}$ dates and a suite of high field strength elements (HFSE) and rare earth elements (REE). Zircons were ablated with a laser diameter of 25 or 40 micrometres using fluence and pulse rates of $\sim 5 \mathrm{~J} / \mathrm{cm}^{2}$ and $10 \mathrm{~Hz}$, respectively, during a 45 second analysis (15 sec gas blank, $30 \mathrm{sec}$ ablation) that excavated a pit $\sim 25 \mu \mathrm{m}$ deep. Ablated material was carried by a $1.2 \mathrm{~L} / \mathrm{min} \mathrm{He}$ gas stream to the $0.8 \mathrm{~L} / \mathrm{min}$ nebulizer flow of the plasma. Specific analyte dwell times, background subtraction, elemental and isotopic calibration methods, and error propagation algorithms are described in Rivera et al. (2013). Quoted uncertainties on the isotopic ratios and dates in the data table are based upon analytical counting statistics for the purpose of intercomparison of dates in our screening study. While not the purpose of our work here, the calculation of absolute age uncertainties on individual data points or group statistics should include propagation in quadrature of the calibration uncertainties noted in the footnote to the data table.

The procedure for $\mathrm{U}-\mathrm{Pb}$ geochronology using isotope dilution thermal ionization mass spectrometry follows that given by Davydov et al. (2010). Zircon crystals were subjected to a modified version of the chemical abrasion (CA-TIMS) method of Mattinson (2005), enabling carefully selected single crystal fragments to be prepared and analysed. Many analyses were made on crystals previously mounted, polished and imaged by cathodoluminence (CL), and selected on the basis of zoning patterns and spot laser ablation inductively coupled plasma (LA-ICPMS) analyses. U-Pb dates and uncertainties for each analysis were calculated using the algorithms of Schmitz and Schoene (2007) and the $U$ decay constants of Jaffey et al. (1971). Other details of the analytical conditions are given in the notes that accompany Table 1. The analyses were carried out in the Isotope Geology Laboratory of the Department of Geosciences at the College of Arts and Sciences, Boise State University, Idaho, USA. Uncertainties are due to non-systematic analytical errors, including counting statistics, instrumental fractionation, tracer subtraction, and blank subtraction. These error estimates should be considered when comparing our ${ }^{206} \mathrm{~Pb} /{ }^{238} \mathrm{U}$ dates with those from other laboratories that have used tracer solutions calibrated against the EARTHTIME gravimetric standards. When comparing our dates with those derived using other decay schemes (e.g., ${ }^{40} \mathrm{Ar} /{ }^{39} \mathrm{Ar}$, ${ }^{187} \mathrm{Re} /{ }^{187} \mathrm{Os}$ ), the uncertainties in tracer calibration (0.05\%; Condon et al., 2007) and $U$ decay constants $(0.108 \%$; Jaffey et al., 1971) should be added to the internal error in quadrature. Quoted errors for calculated weighted means are thus of the form $\pm X(Y)[Z]$, where $X$ is solely analytical uncertainty, $Y$ is the combined analytical and tracer uncertainty, and $Z$ is the combined analytical, tracer and ${ }^{238} U$ decay constant uncertainty.

The mineral composition of the clay fraction of the volcaniclastic horizon was determined by X-ray powder diffraction analysis at the Institute of Geological Engineering (VŠB Technical University in Ostrava). Representative samples were measured after crushing the material to a grain size below ca. $20 \mu \mathrm{m}$ and also analysing the sedimented clay fraction of grain size below $1 \mu \mathrm{m}$. These clay fractions were prepared by sedimentation in demineralised water after disintegration and dispersion of the samples using ultrasound. Samples of the clay fraction were measured in a natural state, and after saturation with ethylene glycol (saturation in vapour at $50^{\circ} \mathrm{C}$ for 12 hours) and after heating to $250^{\circ} \mathrm{C}$ for one hour. Carbonates and Fe ox- 


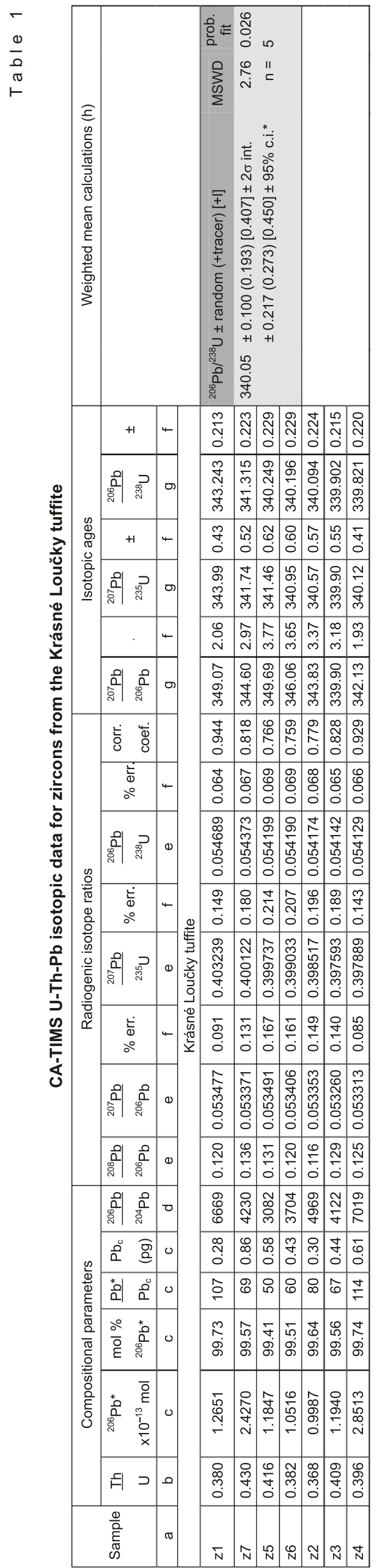

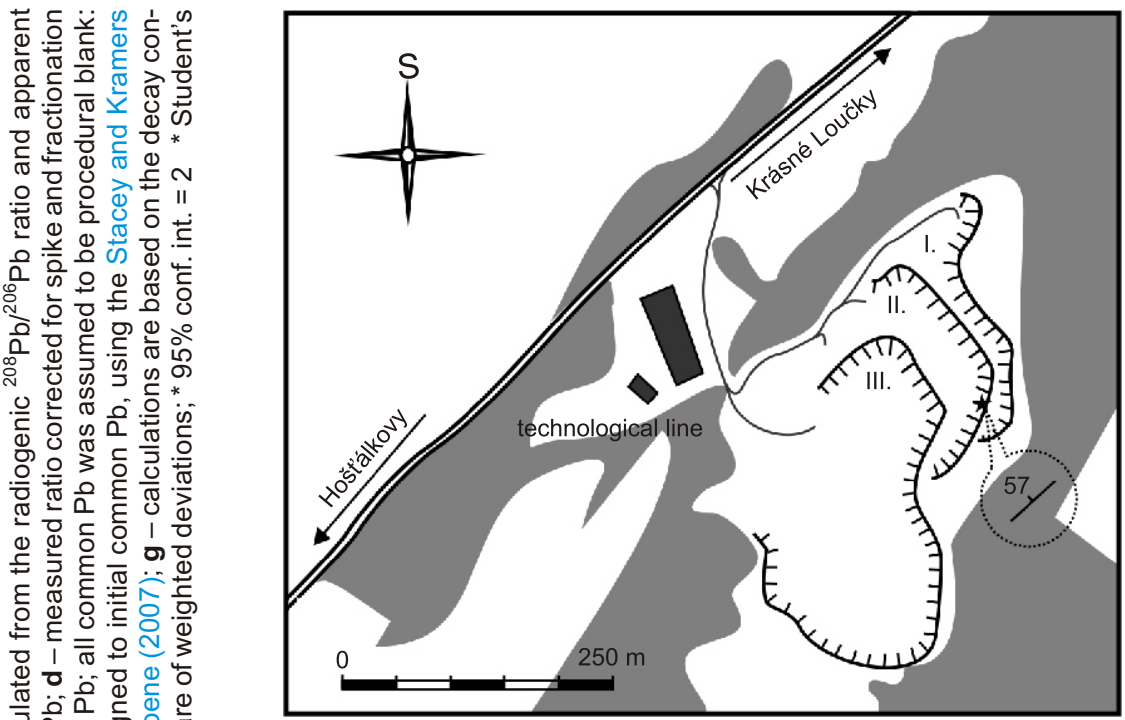

Fig. 2. Sketch-map of Kobylí Quarry

The position of the volcaniclastic layers is marked by a black asterisk; the direction of strike and dip are also indicated

ides and hydroxides were not removed from the samples. Measurements were carried out using a Bruker-AXS D8 Advance instrument with $2 \Theta / \Theta$ geometry measured using a LynxEye position-sensitive detector under the following conditions: radiation CoK $\alpha / F e$ filter, accelerating voltage $40 \mathrm{kV}$, current $40 \mathrm{~mA}$, step by step mode with $0.0142 \Theta$ with an interval of $1 \mathrm{sec}$ per step. The data were digitally processed using Bruker Diffrac Suite software. Semi-quantitative analyses of the phase composition were carried out on samples of grain size $<20 \mu \mathrm{m}$ by means of the Rietveld method using the Bruker Topaz version 4.2 program.

The morphology of zircon grains on the fracture surfaces of samples was examined in the Institute of Geological Engineering (VŠB - Technical University in Ostrava) using an FEI Quanta 650 FEG scanning electron microscope equipped with EDX, WDA, EBSD and CL detectors. The observation was carried out under low vacuum (50 $\mathrm{Pa}$ ) on specimens which were not coated by conductive layer. Only semi-quantitative analyses of the compositions of the grains were made using EDX. In addition to the zircon grains, other phases containing concentrations of heavier elements were also located using backscattered electron imagery and analysed using EDX.

The petrology of thin sections of representative samples was studied under the microscope using transmitted light. Semiquantitative estimates of each component were made.

A petrographic study of samples from two layers of the sedimentary rock rich in organic matter from the vicinity of the volcaniclastic rock was made to determine the character of the organic matter. Both thin sections and polished grain mounts were prepared. Fractions of these samples were ground to less than $0.2 \mathrm{~mm}$ for analysis of ash, sulphur, organic and inorganic carbon contents.

The light reflectance of dispersed organic matter (DOM) was determined in three samples of rock which were cut and polished in section perpendicular to bedding. Measurement of random reflectance of the prevailing types of organic particles was made in normal light at $\lambda=542 \mathrm{~nm}$ using an Opton-Zeiss microscope-microphotometer with oil objectives (magnification $40 \times$ and $100 \times)$, and oil immersion $(n=1.518)$. The maximum reflectance and optical anisotropy were determined under the polarized light at the same equipment and measurement conditions. Zircon $(R=3.12 \%)$ and strontium titanate $(R=5.41 \%)$ were used as optical standards to calibrate measurements. The size, shape, and optical anisotropic texture of the organic 


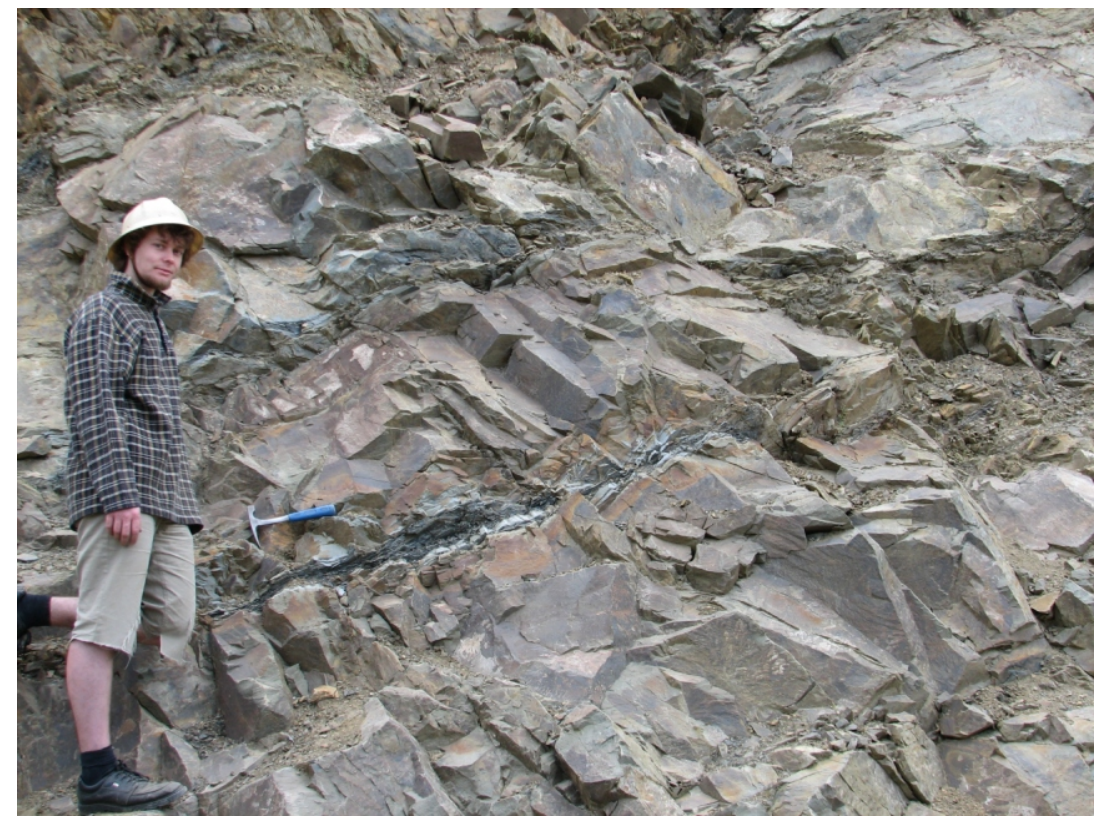

Fig. 3. Layer of the light grey volcaniclastic material exposed in the central part of the eastern face of the second level of the quarry (GPS coordinates N 507'12.79" E $\left.017^{\circ} 37^{\prime} 42.89 "\right)$, state of June 2012 (photo J. Jirásek)

matter were classified according to Diessel et al. (1978), Suchy et al. (1997, 2007), Kwiecińska and Petersen (2004), and Kríbek et al. (2008).

The content of organic matter was determined by elemental analysis after dissolving the inorganic carbonates using $1 \mathrm{~N} \mathrm{HCl}$ and heating to $80^{\circ} \mathrm{C}$. The elemental analysis was carried out using a Flash FA 1112 Thermo Finnigan CHNS/O micro-analyser in the Institute of Rock Structure and Mechanics at the Academy of Sciences of the Czech Republic.

\section{RESULTS}

Two to three layers of pale grey volcaniclastic material were identified in the central part of the eastern face of the second level of the quarry (Figs. 2 and 3, the coordinates N 50 ${ }^{\circ}{ }^{\prime} 12.79 "$ $\left.\mathrm{E} 017^{\circ} 37^{\prime} 42.89^{\prime \prime}\right)$. They are concordant to the bedding and the separation between them is approximately $1.5 \mathrm{~m}$. Their average strike and dip derived from ten measurements is $48 / 57 \mathrm{NW}$.

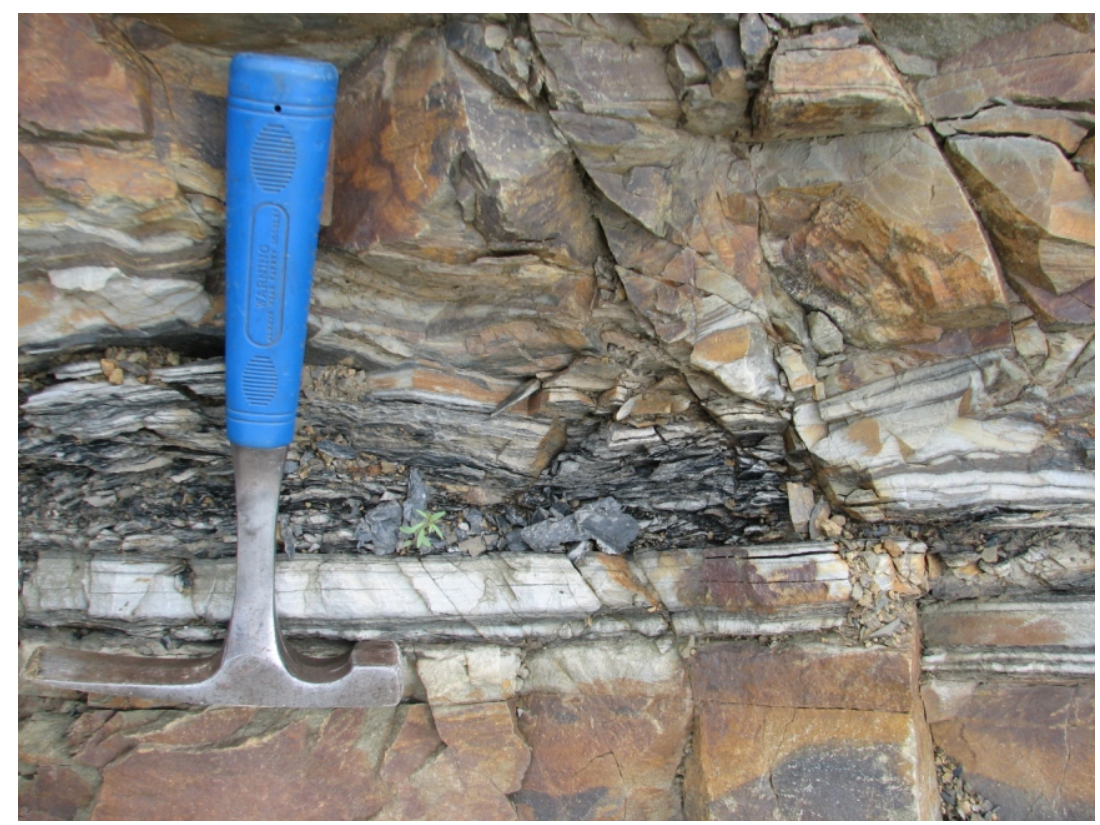

Fig. 4. Layer of volcaniclastic material (tuffite) within the greywacke sequence

The layer shows evidence of tectonic disturbance; laminae of grey-black organic matter alternate with the pale tuffaceous detritus (photo J. Jirásek, 2012) 

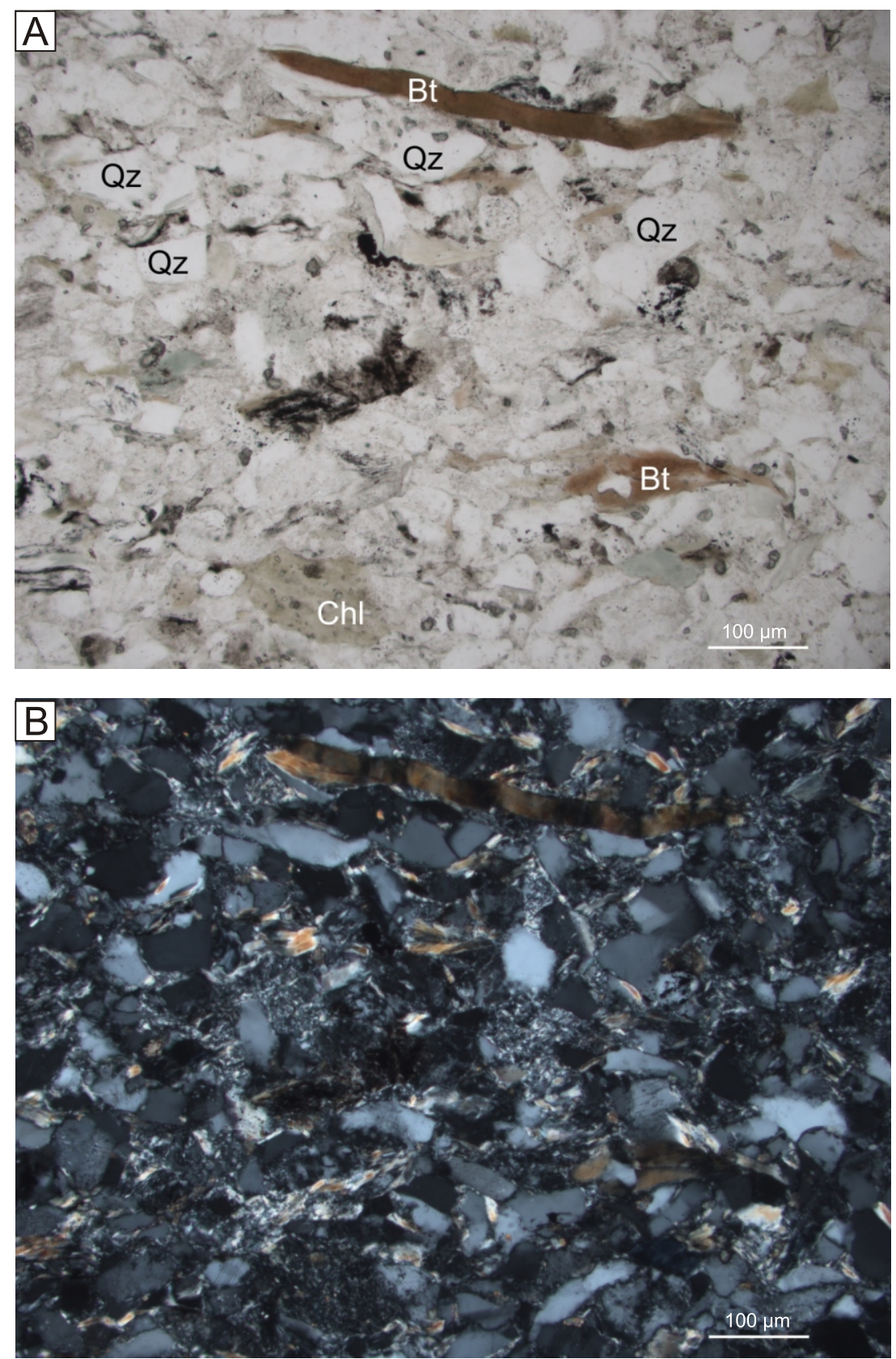

Fig. 5. Photomicrograph of a thin section of the volcaniclastic material in plane polarized light $(A)$ and between crossed polars (B)

Angular and subangular quartz grains $(\mathrm{Qz})$, the former most likely of volcaniclastic origin, together with plates of biotite (Bt), partly or completely chloritized (Chl) in clay matrix with disseminated organic matter

The thickness of the horizons ranges from 1 to $10 \mathrm{~cm}$, and they are traceable for a minimum distance of $8 \mathrm{~m}$. Intervals of graded bedding and dark laminae richer in organic matter can be seen by naked eye within these volcaniclastic layers (Fig. 4).

\section{COMPOSITION OF THE NEWLY EXPOSED TUFFITE}

Thin sections of the samples collected from the volcaniclastic horizon show that it is fine-grained psammitic sediment with a high proportion of clay and can be classified as an arkosic greywacke. Quartz grains are abundant. In addition to the more rounded grains, there are angular fragments which are presumably of volcanic origin. Feldspar, tabular aggregates of muscovite and biotite, in places chloritised, are less abundant (Fig. 5). Accessory minerals were not investigated in detail.

Diffraction patterns of representative samples of the volcaniclastic rock show that the main constituents are quartz, illite-muscovite, $1.4 \mathrm{~nm}$ minerals (chlorite, illite-smectite), plagioclase and potassium feldspar. The results of semi-quantitative analyses show that the quartz content is relatively low (ca. $40 \mathrm{wt} . \%$ ). The content of illite mica (illite, illite-muscovite) is estimated to be $35 \mathrm{wt} . \%$. The contents of plagioclase are relatively high, varying between 15 and $20 \mathrm{wt} . \%$. The $1.4 \mathrm{~nm}$ min- 


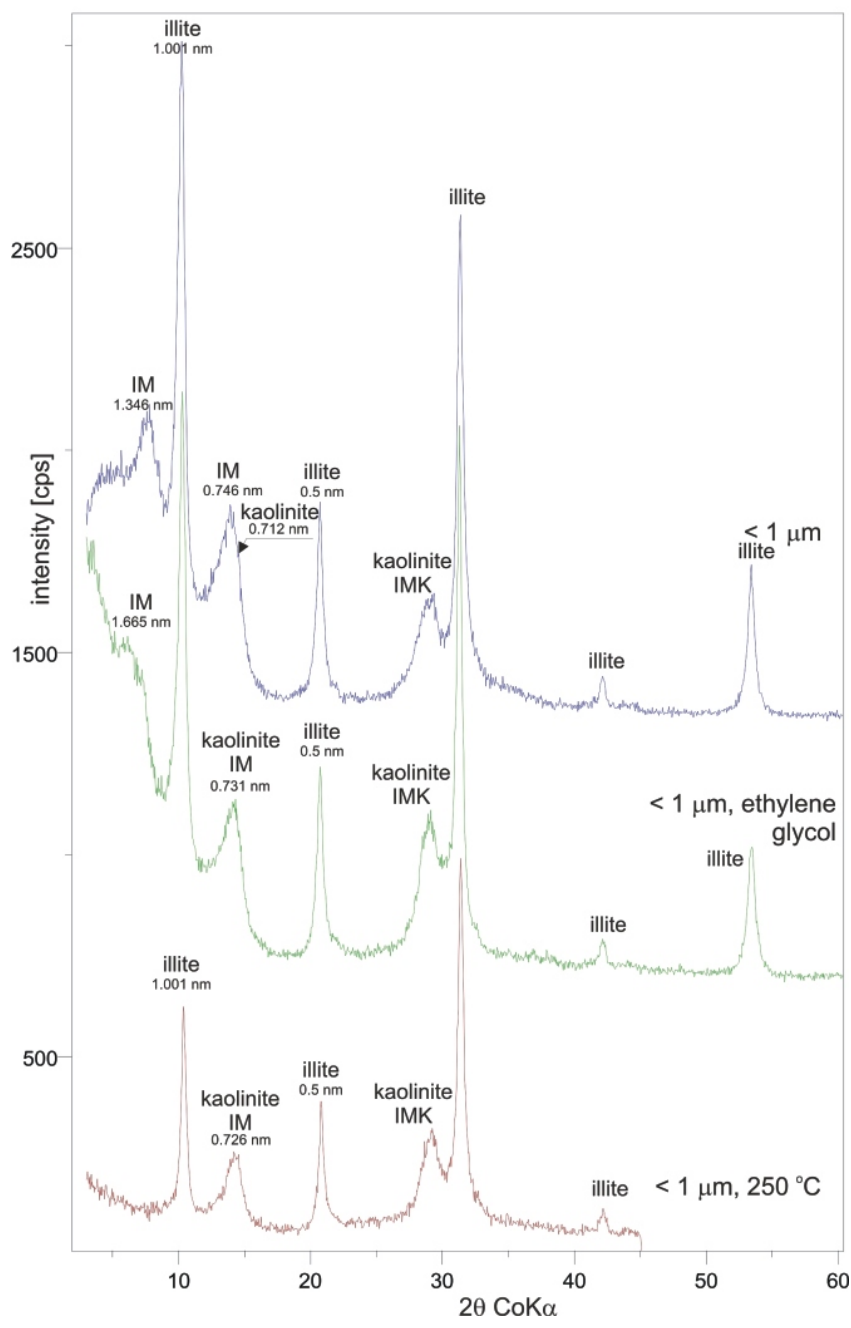

Fig. 6. XRD powder diffractograms of the sedimented fine-grained fraction from the volcaniclastic layer

The peaks of the natural sample are compared with those from the sample saturated with ethyene glycol and after heating to $250^{\circ} \mathrm{C}$; IM illite-smectite (montmorillonite), IMK - illite-smectite (montmorillonite)-kaolinite

eral (chlorite, illite-smectite) is characterized by a distinctly broadened (001) diffraction peak with a half-height width of up to $1.5^{\circ} 2 \Theta$. Evidently several mineral phases contribute to this diffraction peak. For the purpose of semi-quantitative analysis this pattern can be approximated by using the disordered chlorite structure. Estimation of chlorite content then corresponds to 4-8 wt. \%. Only traces of potassium feldspar were detected, though one sample contained up to 2 wt.\%. Lattice parameters of the plagioclase updated by the Rietveld method match those of albite based on the published nomograms (e.g., Kroll, 1983). Refined lattice parameters for plagioclase are as follows: $a_{0}=0.814143(75)$ to $0.8147445(74) \mathrm{nm}, \mathrm{b}_{0}=$ $1.27968(13)$ to $1.28039(12) \mathrm{nm}, \mathrm{c}_{0}=0.715747(49)$ to $0.716052(66) \mathrm{nm}, \alpha=94.220(13)^{\circ}$ to $94.3457(98)^{\circ}, \beta=$ $116.5739(51)^{\circ}$ to $116.6019(60)^{\circ}, \quad \gamma=87.7870(68)^{\circ}$ to $87.90499(80)^{\circ}$. The $R_{w p}$ error parameter of Rietveld analyses ranged from 9.7 to $10.8 \%$. A higher content of plagioclase (about $8 \mathrm{wt} . \%$ ) was found in a sample of shale from the same locality. This sample of shale also contains a $1.4 \mathrm{~nm}$ mineral, matching well with chlorite.
X-ray powder diffraction analysis (XRD) of the sedimented clay fraction with a grain size below $1 \mu \mathrm{m}$ showed that samples of the psammitic rock with an assumed admixture of tuffitic material contain a significant proportion of polycomponent clay material. The main component of the clay fraction consists of mica minerals (illite-muscovite). The diffraction patterns show a rational sequence of peaks with interlayer spacings of $1.0 \mathrm{~nm}$, $0.5 \mathrm{~nm}$ and $0.25 \mathrm{~nm}$. The peaks of the mica mineral do not shift after saturation with ethylene glycol or with heating. Moreover, the diffraction patterns also show peaks for a mineral indicating an interlayer spacing of 1.35 to $1.45 \mathrm{~nm}$. After saturation with ethylene glycol the peaks shift to values from 1.60 to $1.66 \mathrm{~nm}$ and disappear after heating or the interlayer distance becomes the same as for illite. This behavior is typical of the mixed structures of illite-smectite type with a high proportion of the smectite component. The diffractograms also contain relatively broad diffraction peaks corresponding to an interlayer distance of $0.7 \mathrm{~nm}$, which match that of minerals of the kaolinite group. The width of these peaks is affected to some extent by peaks of a mixed structure. After heating to $250^{\circ} \mathrm{C}$, the samples show a peak for the $0.7 \mathrm{~nm}$ spacing that is also quite wide, which suggests the presence of a mixed structure of three components containing a proportion of kaolinite. The small proportion of the mixed structure component in the samples did not allow more precise conclusions to be drawn. The results of XRD analysis of the clay fraction in a sample are shown in Figure 6.

The morphology of the zircon grains in samples of the psammitic rock was studied using scanning electron microscopy and energy dispersive microanalysis. It was found that zircon is a relatively rare accessory and shows marked variations in grain size and morphology (Fig. 7). It is obvious that the samples contain several populations of zircons. It is possible to find columnar, thin, perfectly developed crystals with a length under $85 \mu \mathrm{m}$, also semi-rounded zircon grains showing signs of crystal edges about 10-40 $\mu \mathrm{m}$ in length, and almost perfectly rounded zircon grains $20-40 \mu \mathrm{m}$ in diameter. Other accessory minerals include framboidal pyrite up to $10 \mu \mathrm{m}$ in size, microcrystals of barite confined to tiny fractures, grains and also aggregates of imperfectly developed columnar microcrystals of rare earth phosphate with predominance of $\mathrm{Ce}$ (probably rhabdophane) and rare grains of a phosphate rich in Th. Coatings and very thin aggregates of fluorocarbonate of $\mathrm{Ca}$ and $\mathrm{Ce}$ were found on the foliation planes of the shales. The mineral is likely to be a member of the bastnäsite or synchysite group.

Tiny amounts of dispersed secondary lead minerals were found in micro-fractures in the psammitic rock. Microcrystalline pseudomorphs after galena crystals up to $50 \mu \mathrm{m}$ across consisting of a mixture of anglesite and cerussite were identified. In the vicinity of these pseudomorphs there is a zone of microcrystalline pyromorphite-vanadinite occupying fractures. Individual acicular crystals and aggregates range between 5 and $10 \mu \mathrm{m}$ in size. Grains in which the vanadium content is higher than that of phosphorus tend to form at a greater distance from the galena pseudomorphs and are usually of elongate columnar form. Grains in which phosphorus is more abundant than vanadium occur closer to the pseudomorphs and take the form of small spherical bodies showing only traces of crystal planes on their surface.

\section{U-PB GEOCHRONOLOGY}

Sample GP-8 from the Krásné Loučky tuffite yielded a mixed population of silt to fine sand-sized zircon grains, ranging from skeletal, highly elongate, prismatic crystals to rounded equant grains (Fig. 7). From the mineral separate, the most 

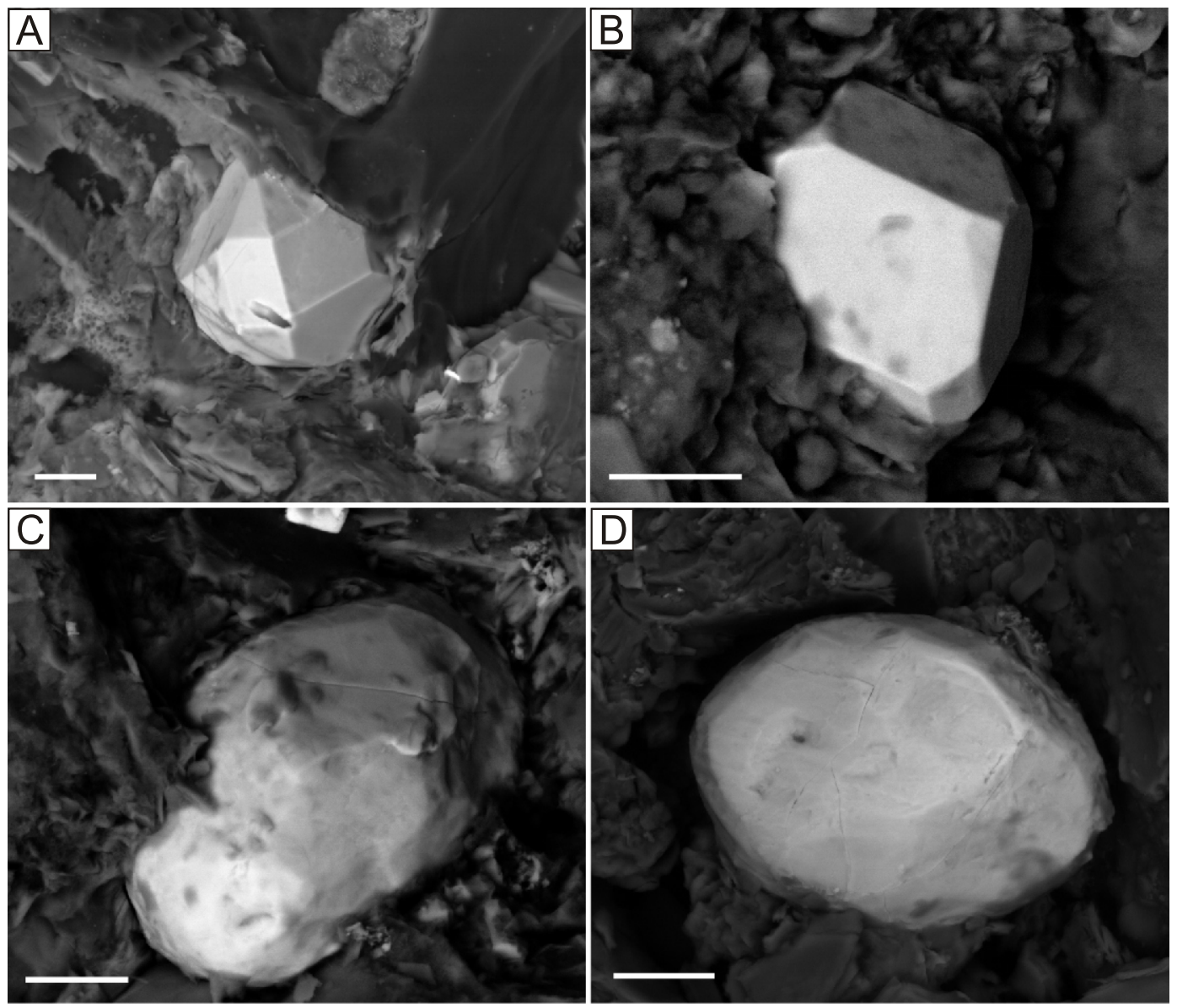

Fig. 7. BSE images of two different zircon populations from the volcaniclastic horizon

A, B - euhedral volcanic zircon crystals; C, D - rounded detrital zircon grains; white scale bar is $10 \mu \mathrm{m}$

sharply faceted crystals were selected and mounted for CL imaging, which revealed a diversity of luminescence intensities and zoning patterns (Fig. 8). LA-ICPMS spot ages confirmed this diversity, including one crystal dated at $2.0 \mathrm{Ga}$, a population of Cambro-Ordovician grains (544 to $448 \mathrm{Ma}$ ), and a dominant population of grains with ages grouped around ca. $340 \mathrm{Ma}$ (see Appendix $\left.1^{*}\right)$. This latter group of ages was obtained from both CL-dark and CL-bright crystals.

Seven single zircon grains selected on the basis of CL-dark patterns and young LA-ICPMS spot ages yielded, by CA-TIMS a range of ${ }^{206} \mathrm{~Pb} /{ }^{238} \mathrm{U}$ dates from 343.2 to $339.8 \mathrm{Ma}$ (Fig. 9 and Table 1). The two older grains are interpreted as reworked detritus or inherited xenocrysts. The five youngest grains cluster around a weighted mean ${ }^{206} \mathrm{~Pb} /{ }^{238} \mathrm{U}$ date of $340.05 \pm$ $0.22(0.27)[0.45] \mathrm{Ma}(\mathrm{MSWD}=2.76)$, which, given their reproducibility is assumed to correspond to the age of eruption and deposition of the tuff.

\section{ANALYSIS OF ORGANIC MATTER}

We collected new samples from the layers rich in organic matter that are stratigraphically close to the volcaniclastic horizons. These layers are up to $10 \mathrm{~cm}$ thick and macroscopically resemble bituminous coal. Analyses showed that these are pelitic rocks with a mixture of various types of dispersed organic matter (DOM) that indicate varying thermal transformation. Values of total organic carbon (TOC) range between 0.14 and $6.57 \%$. Carbonaceous matter consists of four types of particles which differ in size, morphology and optical properties. The first type of dispersed organic matter (DOM) is abundant in all samples studied and consists of small $(<10 \mu \mathrm{m})$ irregular (Fig. 10A) or elongated (Fig. 10B) particles. They are dispersed in inorganic matter or are arranged in planes following microtectonic structures. Reflectance values were often difficult to obtain due to small particle size, where measured reflectance values range from 3.11 to $5.71 \%$, and random reflectance $R_{r}$ is $4.32 \%$. The second type of DOM consists of larger (10-50 $\mu \mathrm{m})$ irregular or elongated particles (Fig. 10A, B). Most of the particles are optically isotropic but some exhibit distinct undulatory extinction under crossed polars (Fig. 10B). Reflectance values range from 3.61 to $6.15 \%$ and random reflectance is $4.79 \%$. A third type of dispersed organic matter resembles to fragments of pyrobitumen (Jacob, 1989). Most of the particles occur in the form of relatively large ( $>30 \mu \mathrm{m}$ across), irregular, well-defined fragments (Fig. 10C) which exhibit internal pores, cracks and optical anisotropy that corresponds to a fine-grained mosaic texture. Maximum reflectance values vary from 6.15 to $8.06 \%$ $R_{\max }$. Relatively rare, the fourth type of organic matter represents dispersed structures likely to be of biological origin (Fig. 10C, D). Their reflectance ranges between 4.0 to

* Supplementary data associated with this article can be found, in the online version, at doi: $10.7306 /$ gq.1201 


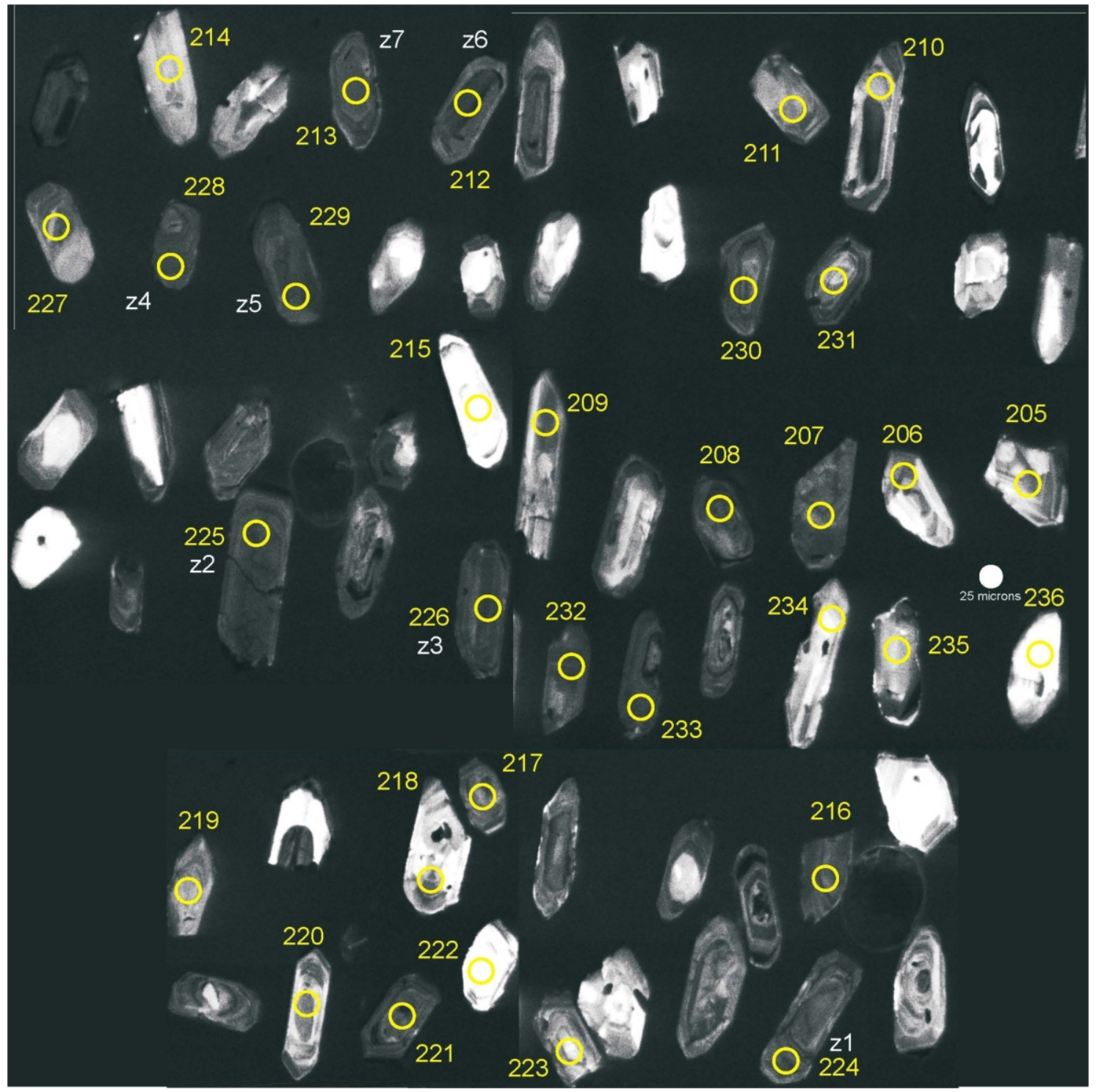

Fig. 8. CL images of Krásné Loučky tuffite zircon crystals shown with LA-ICPMS spot locations

Crystals $z 1$ to $z 7$ correspond to Table 1, numbers 205 to 236 correspond to the Appendix 1; size is indicated by $25 \mu \mathrm{m}$ spot

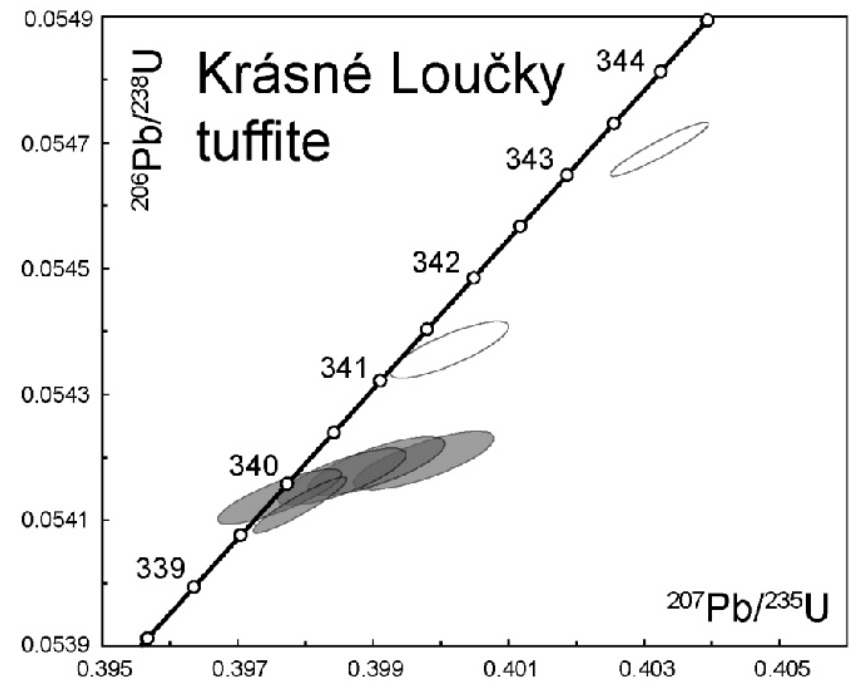

Fig. 9. U-Pb concordia diagram for single zircon grain CA-TIMS analyses from the Krásné Loučky tuffite

Two empty ellipsoids older than $341 \mathrm{Ma}$ are grains $z 1$ and $z 7$ in Table 1 considered to be reworked detritus or inherited xenocrysts (they were not counted for the final age) 

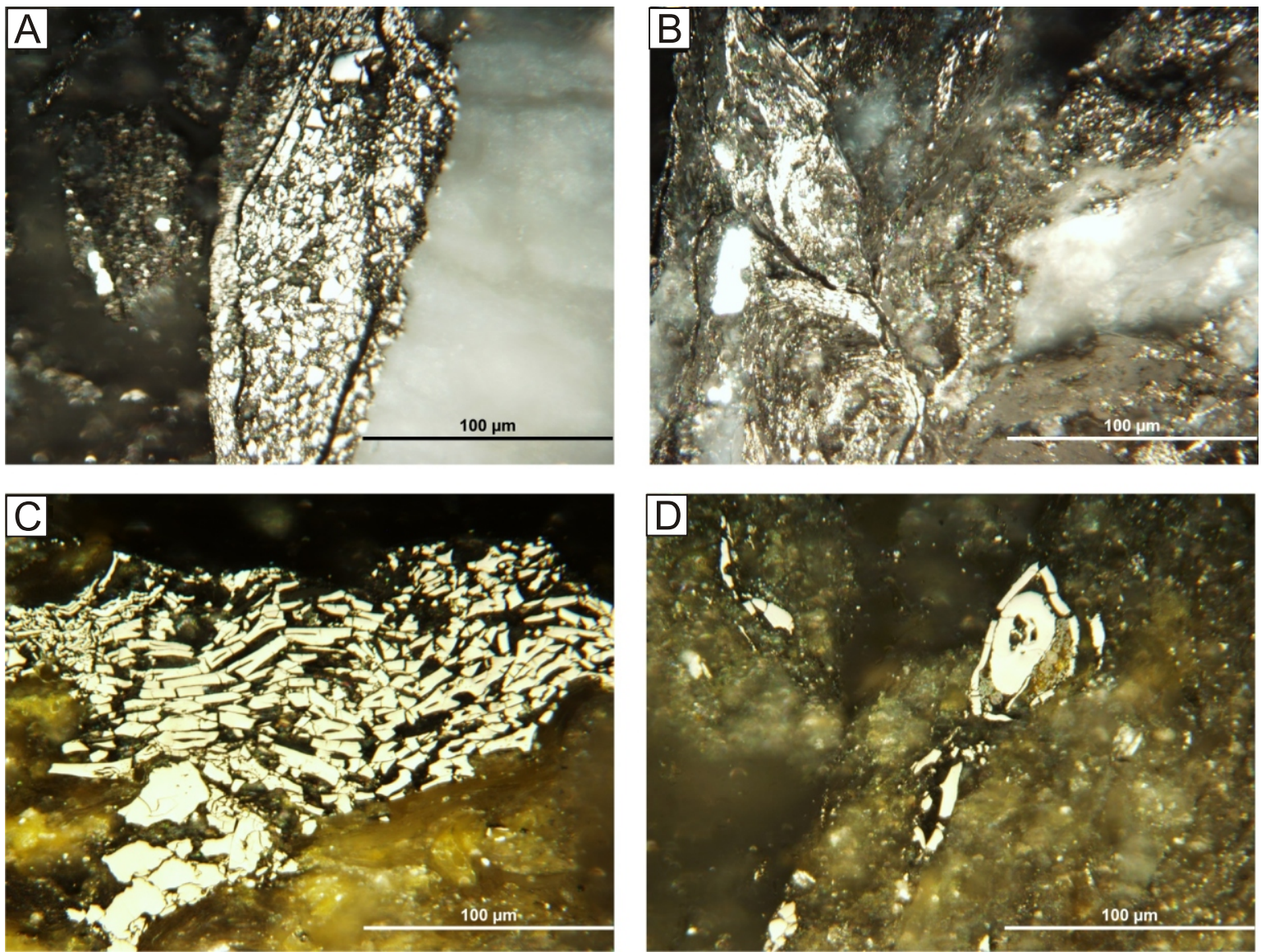

Fig. 10. Reflected light photomicrographs showing characteristic types of dispersed organic matter in the volcaniclastic horizon (oil immersion)

A - mixture of fine- and coarse-grained carbonaceous particles in the rock matrix; B - fine-grained carbonaceous particles aligned along the cleavage plane in the rock matrix (crossed polars); $\mathbf{C}$ - third type of large, highly reflective irregular particles DOM resembling pyrobitumen and a fourth type of fusinite-like structure of biological origin; D - structure of possible biological origin

$5.06 \% R_{r}$. The average reflectance $R_{r}=4.32$ to $4.79 \%$ of the majority of carbonaceous particles suggests anthracite to meta-anthracite rank (ECE-UN, 1998). The rank of the carbonaceous particles can be classified according to maximum reflectance $R_{\max }$ (Kwiecińska and Petersen, 2004): anthracite $\left(R_{\max }<5.0 \%\right)$, meta-anthracite $\left(R_{\max }<6.5 \%\right)$, semi-graphite $\left(R_{\max } 6.5\right.$ to $\left.9.0 \%\right)$ and graphite $\left(R_{\max }>9.0 \%\right)$.

\section{DISCUSSION}

Based on the observations made above, we believe that, after an interval of almost thirty years, we have rediscovered the volcaniclastic horizons in the quarry that may have been the subject of the original dating reported by Prichystal (1987). Even if these new exposures are not identical, their stratigraphic position is thought to be approximately the same. The new date of $340.05 \pm 0.22 \mathrm{Ma}$ obtained from zircons in this volcaniclastic layer is $21 \mathrm{Ma}$ older than the previously published date. This ends the controversy caused by the first date $(319 \pm 2 \mathrm{Ma})$ which suggested that the volcaniclastic horizon belonged to the uppermost part of the Ostrava Formation of the Upper Silesian Basin, i.e. the stratigraphic horizon corresponding to the tonstein contained in coal seam no. 479 in the Poruba
Member. We suggest that the earlier date was likely biased by $\mathrm{Pb}$-loss from the bulk analysis of relatively high- $U$ zircon crystals which were not treated via modern methods (chemical abrasion) of open system crystal domain removal. It was difficult to explain how rocks equivalent to the Ostrava Formation were present $50 \mathrm{~km}$, as the crow flies, from the nearest outcrop of the Poruba Member. Moreover, this distance was probably much greater before folding of the Culm strata (Jirásek et al., 2013b). Because Prichystal (1987) considered the original dating to be correct, he proposed two possible explanations. The first was the preservation of marine sedimentation in a separate basin in the western part of the Nízký Jeseník Mts. that pushes the top of the Horní Benešov Formation into the Namurian. The second explanation offered was that a fragment of the Poruba Member was overthrusted to the west from the Upper Silesian Basin.

The original dating of tuffite from the Krásné Loučky Quarry corresponds approximately to the boundary between the Ostrava and Karviná formations in the Upper Silesian Basin (Jirásek et al., 2013a, b), i.e. in the top of the Poruba Member (ca. $320 \mathrm{Ma}$ ). The new dating places these rocks in the Visean (Davydov et al., 2012), which is compatible with what is known about their geology and biostratigraphic position. Records of the occurrence of spores of Namurian age at the site 
(Přichystal, 1987; Přichystal et al. in Weyer and Menning, 2006) cannot be validated without an authoritative publication. However, it would be difficult to explain their preservation in an environment where the mean reflectance $R_{r}$ of vitrinite is $4.32 \%$ corresponding to a rank of meta-anthracite. If significantly younger sediments had been tectonically incorporated in the local stratigraphic sequence, then this must have happened during the latest Carboniferous, around 310 Ma (Bashkirian, Early Pennsylvanian) when the local Variscan orogenic belt collapsed (Schulmann et al., 2009). This would have been the only possible reason for local tectonic deformation. If strata of $319 \mathrm{Ma}$ age really were present and survived erosion, then they must have been tectonically buried almost immediately after deposition, and their grade of metamorphism should correspond to that of the neighbouring rocks. It is also difficult to imagine that during tectonism the surface material was almost immediately buried to depths of $4-10 \mathrm{~km}$, which is the estimated thickness of the eroded deposits (cf. Francu et al., 2002).

The new studies of the Upper Silesian Basin show that its fill is similar to that of other foredeep basins, and its western flank probably did not have a length of tens of kilometres (Hýlová et al., 2013). In other words, the area of deposition of the Poruba Member could not have extended as far as the town of Krnov. The continuation of marine sedimentation into the Namurian in a separate basin proposed by Prichystal (1987) for the Horn Benešov Formation has no real justification because, to the contrary, the uplift of the orogenic belt in the west caused progressive erosion of the fill in the basin that was cannibalized to create younger sediments. The hypothesis of "reverse overthrusting" proposed by Prichystal (1987) based on the work of Cháb (1986) has already been proved incorrect by Dvořák (1986).

In addition to zircon grains of Visean age, older populations of zircon were identified. The origin of the single grain of Paleoproterozoic age is not clear, but might be derived from older material incorporated into Brunovistulicum during the Pan-African (Cadomian) orogeny. More abundant Cambro-Ordovican grains are consistent with the age of granitoids in the Desná Dome (Kröner et al., 2000). These results are in agreement with the interpretation of heavy mineral associations described by Hartley and Otava (2001), who identified their source in strata and in meta-igneous rocks.

Diffraction patterns of the clay fraction from the Krásné Loučky samples of psammite with admixed tuffitic material are not identical to those of clay fractions from other Late Carboniferous volcaniclastic horizons from the Upper Silesian Basin (e.g., Dopita and Králík, 1977; Horák et al., 1992). Tuffitic rocks (the so-called whetstones, tonsteins, tuffites) from the Upper Silesian Basin contain a significant proportion of disordered mixed structures such as illite-smectite with a lower content of the smectite component. In fact, the grade of metamorphism is significantly lower $\left(R_{o} 0.5\right.$ to $\left.2.0 \%\right)$ in the Upper Silesian Basin than in the Culm strata $\left(R_{o} 2.0\right.$ to $\left.5.5 \%\right)$. The difference in min- eralogy may be due to the fact that the volcaniclastic material in the Upper Silesian Basin was deposited in a terrestrial environment, while at the Krásné Loučky site, deposition took place in a marine environment.

Having obtained further datable material from the flysch strata of the Culm from the Moravo-Silesian Paleozoic Basin, it will be possible to resolve the long-standing debate about the relative age of these formations. It will also be possible to make an effective correlation with other foredeep Variscan basins in Europe that were filled at the beginning of the orogeny by Early Carboniferous flysch, e.g. the Rhenohercynian Turbidite Basin in Germany (Ricken et al., 2000), the Culm and South Wales Carboniferous basins in Britain (Hartley and Warr, 1990) and the basins of the Franco-Spanish Pyrenees (Delvolvé et al., 1998).

\section{CONCLUSIONS}

Arkosic greywackes with a significant volcaniclastic component (tuffites) were rediscovered in the second level of the active quarry at Krásné Loučky - Kobylí near the town of Krnov. We interpret them as redeposited volcanic ash washed down from the adjacent mainland into a foreland basin. In addition to older zircon grains (exceptionally Paleoproterozoic, commonly of Cambro-Ordovican age) grains with ages clustered around ca. 340 Ma were found to be most abundant. The CA-TIMS $\mathrm{U}-\mathrm{Pb}$ age of $340.05 \pm 0.22 \mathrm{Ma}$ that was determined is different to the previously published age of $319( \pm 2,3,21) \mathrm{Ma}$ (Prichystal, 1987) determined using samples assumed to be from stratigraphically identical material. If this assumption is justified, then no isolated occurrences of sediments of this age are present west of the present boundary of the Upper Silesian Basin. The new date also defines an approximate age for the boundary between the Horní Benešov and Moravice formations of the Culm flysch in the Nízký Jeseník Mts.

Acknowledgements. This study was made possible thanks to a grant from the Ministry of Education, Youth and Sports (project SGS SP2014/40). We also thank KAMENOLOMY ČR s.r.o., part of the STRABAG SE, particularly K. Selvek and Ing. A. Maleňáková for admission to the quarry and permission to collect the samples from which the new dates were obtained. Part of the analytical work was performed on equipment financed by the project "Institute of Clean Technologies for Mining and Utilization of Raw Materials for Energy Use", reg. no. CZ.1.05/2.1.00/03.0082, supported by the "Research and Development for Innovations Operational Programme" which is financed by structural funds from the European Union and by means of the state budget of the Czech Republic. We are grateful for the inspiring notes of A. Hartley and J. Otava. The detailed reviews of M. Kusiak, M. Paszkowski, and anonymous reviewer improved our manuscript considerably.

\section{REFERENCES}

Bábek, O., Mikuláš, R., Zapletal, J., Lehotský, T. 2004. Combined tectonic-sediment supply-driven cycles in a Lower Carboniferous deep-marine foreland basin, Moravice Formation, Czech Republic. International Journal of Earth Sciences, 93: 241-261
Bábek, O., Přikryl, T., Hladil, J., 2007. Progressive drowing of carbonate platform in the Moravo-Silesian Basin (Czech Republic) before Frasnian/Famennian event: facies, compositional variations and gamma-ray spectrometry. Facies, 53: 293-316. 
Buła, Z., Żaba, J., 2005. Pozycja tektoniczna Górnośląskiego Zagłębia Węglowego na tle prekambryjskiego i dolnopaleozoicznego podłoża (in Polish). In: LXXVI Zjazd Naukowy Polskiego Towarzystwa Geologicznego (eds. J. Jureczka, Z. Buła and J. Żaba): 15-42. Państwowy Instytut Geologiczny, Warszawa.

Cháb, J., 1986. Tectonics of the Moravo-Silesian branch of the European Late Paleozoic orogene (a working hypothesis) (in Czech with English abstract). Věstník Ústředního Ústavu Geologického, 61: 113-120.

Cháb, J., 2010. Basement: Variscan orogen. In: Outline of the Geology of the Bohemian Massif: the Basement Rocks and their Carboniferous and Permian Cover (ed. J. Cháb): 27-113. Czech Geological Survey Publishing House, Prague.

Condon, D., Schoene, B., Bowring, S., Parrish, R., McLean, N., Noble, S., Crowley, Q., 2007. EARTHTIME: isotopic tracers and optimized solutions for high-precision U-Pb ID-TIMS geochronology. Eos, Transactions American Geophysical Union, 88,abstract \#V41E-06.

Davydov, V.I., Crowley, J.L., Schmitz, M.D., Poletaev, V.I., 2010. High-precision U-Pb zircon age calibration of the global Carboniferous time scale and Milankovitch band cyclicity in the Donets Basin, eastern Ukraine. Geochemistry Geophysics Geosystems, 11: 1-22.

Davydov, V.I., Korn, D., Schmitz, M.D., 2012. The Carboniferous Period. In: The Geologic Time Scale 2012, 2 (eds. F.M. Gradstein, J.G. Ogg, M.D. Schmitzand and G.M. Ogg): 603-651. Elsevier, Oxford.

Delvolvé, J.-J., Vachard, D., Souquet, P., 1998. Stratigraphic record of thrust propagation, Carboniferous foreland basin, Pyrenees, with emphasis on Pays-de-Sault (France/Spain). Geologische Rundschau, 87: 363-372.

Diessel, C.F.K., Brothers, R.N., Black, P.M., 1978. Coalification and graphitization in high-presure schists in New Caledonia. Contributions to Mineralogy and Petrology, 68: 63-78.

Dopita, M., Králík, J., 1977. Coal tonsteins in Ostrava-Karviná Coal Basin (in Czech with English summary). OKD, Ostrava.

Dvořák, J., 1986. K problému príkrovové stavby $v$ evropských variscidách, zvláště na Moravě (in Czech). Časopis pro mineralogii a geologii, 31: 93-98.

Dvořák, J., 1994. Variscan flysch development in the Nízký Jeseník Mts. in Moravia and Silesia (in Czech with English summary). Czech Geological Survey, Prague.

ECE-UN, 1998. International Classification of in-Seam Coals. United Nations, Geneva.

Francu, E., Francu, J., Kalvoda, J., Poelchau, H.S., Otava, J., 2002. Burial and uplift history of the Palaeozoic Flysch in the Variscan foreland basin (SE Bohemian Massif, Czech Republic). EGU Stephan Mueller Special Publication Series, 1: 167-179.

Grygar, R., Vavro, M., 1995. Evolution of Lugosilesian Orocline (North-eastern periphery of the Bohemian Massif): kinematics of Variscan deformation. Journal of the Czech Geological Society, 40: 65-90.

Hartley, A.J., Otava, J., 2001. Sediment provenance and dispersal in a deep marine foreland basin: the Lower Carboniferous Culm Basin, Czech Republic. Journal of the Geological Society, 158 : 137-150.

Hartley, A.J., Warr, L.N., 1990. Upper Carboniferous foreland basin evolution in SW Britain. Proceedings of the Ussher Society, 7 : 212-216.

Hladil, J., Dvořák, J., 1994. Carboniferous. In: Geological Atlas of the Czech Republic - Stratigraphy (ed. J. Klomínský). Czech Geological Survey, Prague.

Horák, J., Sýkora, J., Hoch, I., Hemza, P., Filák, P., Martinec, P., Weiss, Z., Chmielová, M., 1992. Tufogenní horizonty v OKR: Katalog (in Czech). Důlní průzkum a bezpečnost, Paskov.

Hýlová, L., Jureczka, J., Jirásek, J., Sivek, M., Hotárková, J., 2013. The Petřkovice Member (Ostrava Formation, Mississippian) of the Upper Silesian Basin (Czech Republic and Poland). International Journal of Coal Geology, 106: 11-24.
Jacob, H., 1989. Classification, structure, genesis and practical importance of natural solid oil bitumen ("migrabitumen"). International Journal of Coal Geology, 11: 65-79.

Jaffey, A.H., Flynn, K.F., Glendenin, L.E., Bentley, W.C., Essling, A.M., 1971. Precision measurements of half-lives and specific activities of ${ }^{235} \mathrm{U}$ and ${ }^{238} \mathrm{U}$. Physical Review C, 4: 1889-1906.

Jirásek, J., Sedláčková, L., Sivek, M., Martínek, K., Jureczka, J., 2013a. Castle Conglomerate Unit of the Upper Silesian Basin (Czech Republic and Poland): a record of the onset of Late Mississippian C2 glaciation? Bulletin of Geosciences, 88: 893-914.

Jirásek, J., Hýlová, L., Sivek, M., Jureczka, J., Martínek, K., Sýkorová, I., Schmitz, M., 2013b. Major Mississippian volcaniclastic unit of the Upper Silesian Basin, the Main Ostrava Whetstone: composition, sedimentary processes, palaeogeography and geochronology. International Journal of Earth Sciences, 102: 989-1006.

Kalvoda, J., Babek, O., Fatka, O., Leichmann, J., Melichar, R., Nehyba, S., Spacek, P., 2008. Brunovistulian terrane (Bohemian Massif, Central Europe) from late Proterozoic to late $\mathrm{Pa}$ leozoic: a review. International Journal of Earth Sciences, 97: 497-518.

Kandarachevová, J., Sedláčková, L., Hýlová, L., Jirásek, J., Sivek, M., 2009. Lateral development of coalification in the Czech part of the Upper Silesian Coal Basin and its connection with gas deposits. International Journal of Coal Geology, 78: 225-232.

Karkusz, L., 1989. Štruktúrno-geologické mapovanie kulmských sedimentov $\mathrm{v}$ širšom okolí ložiska drôb v Krásných Loučkách u Krnova (in Slovak). Dissertation, Jan Evangelista Purkyně University, Brno.

Krogh, T.E., 1973. A low-contamination method for hydrothermal decomposition of zircon and extraction of $\mathrm{U}$ and $\mathrm{Pb}$ for isotopic age determinations. Geochimica et Cosmochimica Acta, 37: 485-494.

Kroll, H., 1983. Lattice parameters and determinative methods for plagioclase and ternary feldspars. In: Feldspar Mineralogy, 2 (ed. P.H. Ribbe): 57-98. Mineralogical Society of America.

Kröner, A., Štípská, P., Schulmann, K., Jaeckel, P., 2000. Chronological constrains on the pre-Variscan evolution of the northeastern margin of the Bohemian Massif, Czech Republic. Geological Society Special Publications, 179: 175-197.

Krut'a, T., 1954-55. Mineralogické poměry $\mathrm{v}$ kulmských sedimentech ve slezské části Nízkého Jeseníku (in Czech). Acta Musei Silesiae, Historiae naturales, 4: 29-36.

Krut'a, T., 1963. Die Mineralogische Erforschung Schlesiens in den Jahren 1961-1963 (in Czech with German summary). Acta Musei Moraviae, Scientiae naturales, 48: 7-22.

Krut'a, T., 1973. Slezské nerosty a jejich literatura (in Czech). Moravské muzeum v Brně, Brno.

Kř́bek, B., Sýkorová, I., Machovič, V., Laufek, F., 2008. Graphitization of organic matter and fluid-deposited graphite in Palaeoproterozoic (Birimian) black shales of the Kaya-Goren greenstone belt (Burkina Faso, West Africa). Journal of Metamorpic Geology, 26: 937-958.

Kukal, Z., 1980. The sedimentology of Devonian and Lower Carboniferous deposits in the western part of the Nízký Jeseník Mountains, Czechoslovakia. Sborník Geologických Věd, Geologie, 34: 131-207.

Kumpera, O., 1961. Geology of Culm near Krnov and Třemešná (Upper Silesian fore-deep) (in Czech with English summary). Prírodovědecký Časopis Slezký, 22: 491-511.

Kumpera, O., 1966. Stratigraphische, lithologische und tektonische Probleme des Devons und Kulms am Nordrande der Šternberk-Horní Benešov-Zone. Freiberger Forschungshefte, Geologie C, 204: 1-103.

Kumpera, O., 1974. Stratigraphy of the Lower Carboniferous Strata of the Jeseníky Mts. Block: Part 1 - Pre-Culm Series and Horní Benešov Formation (in Czech with English summary). Sborník vědeckých prací Vysoké školy báňské v Ostravě, Řada hornicko-geologická, 20: 133-154. 
Kumpera, O., 1976. Stratigraphy of the Lower Carboniferous Strata of the Jeseníky Mts. Block: Part 2 - Culm Series of Strata and Their Stratigraphic Equivalents - Moravice Formation (in Czech with English summary). Sborník vědeckých prací Vysoké školy báňské v Ostravě, Řada hornicko-geologická, 22: 141-170.

Kumpera, O., 1983. Geologie spodního karbonu jesenického bloku (in Czech). Ústřední ústav geologický, Praha.

Kumpera, O., 1996. Viséská faunistická společenstva a jejich význam pro poznání vývoje flyšových pánví ve středoevropských variscidách (Český masív) (in Czech). In: Seminář k 75. narození Prof. RNDr. Bohuslava Růžičky, CSc.: Ostrava 2-3.4.1996: sborník referátů: 12-13.

Kumpera, O., Martinec, P., 1995. The development of the Carboniferous accretionary wedge in the Moravian-Silesian Paleozoic Basin. Journal of the Czech Geological Society, 40: 47-64.

Kumpera, O., Vašíček, Z., 1961. The geological surveying in the western vicinity of Krnov (in Czech with English summary). Sborník vědeckých prací Vysoké školy báňské v Ostravě, Řada hornicko-geologická, 7: 425-429.

Kwiecińska, B., Petersen, H.I., 2004. Graphite, semi-graphite, natural coke, and natural char classification - ICCP system. International Journal of Coal Geology, 57: 99-116.

Mattinson, J.M., 2005. Zircon U-Pb chemical abrasion ("CA-TIMS") method: Combined annealing and multi-step partial dissolution analysis for improved precision and accuracy of zircon ages. Chemical Geology, 220: 47-66.

Mazur, S., Aleksandrowski, P., Kryza, R., Oberc-Dziedzic, T., 2006. The Variscan Orogen in Poland. Geological Quarterly, 50 (1): 89-118.

McDonough, W.F., Sun, S.S., 1995. The composition of the Earth. Chemical Geology, 120: 223-253.

Novák, J., Horák, J., 1981. Ložisko drob Kobylí u Krnova (in Czech). Sborník GPO, 23: 103-115.

Otava, J., ed., 1984. Vysvětlující text k základní geologické mapě 1:25,000 list 15-134 Brantice (in Czech). Ústřední ústav geologický, Brno.

Patteisky, K., 1929. Die Geologie und Fossilführung der Mährisch-Schlesischen Dachschiefer- und Grauwackenformation. Naturwissenschaftlichen Verein in Troppau, Prag.

Přichystal, A., 1987. Izotopové stáří zirkonu z tufové polohy v kulmských sedimentech nedaleko Krnova (in Czech). In: Sborník referátů $z$ jednání KRB pro rozvoj rudního geofyzikálního průzkumu v Jeseníkách v roce 1985 a 1987 v Loučné nad Desnou: 153-161. Geofyzika, Brno.

Přichystal, A., 1993. Paleozoic to Quaternary volcanism in the geological history of Moravia and Silesia (in Czech with English abstract). In: Geologie Moravy a Sleszka: Sborník príspěvků k 90. výročí narození prof. Dr. Karla Zapletala (eds. A. Přichystal, V. Obstová and M. Suk): 59-70. Moravské zemské muzeum a Sekce geologických věd PřF MU, Brno.

Purkyňová, E., 2003. Fossil megaflora from the Kobylí - quarry in Krásné Loučky near Krnov (Horní Benešov Formation, Jeseník Culm, Lower Carboniferous) (in Czech with English abstract). Časopis Slezského Muzea (A), 52: 97-102.

Ricken, W., Schrader, S., Oncken, O., Plesch, A., 2000. Turbidite basin and mass dynamics related to orogenic wedge growth; the Rheno-Hercynian case. Geological Society Special Publications, 179: 257-280.

Rivera, T.A., Storey, M., Schmitz, M.D., Crowley, J.L., 2013. Age intercalibration of ${ }^{40} \mathrm{Ar} /{ }^{39} \mathrm{Ar}$ sanidine and chemically distinct
U/Pb zircon populations from the Alder Creek Rhyolite Quaternary geochronology standard. Chemical Geology, 345: 87-98.

Schmitz, M.D., Schoene, B., 2007. Derivation of isotope ratios, errors, and error correlations for $\mathrm{U}-\mathrm{Pb}$ geochronology using ${ }^{205} \mathrm{~Pb}^{235} \mathrm{U}-\left({ }^{233} \mathrm{U}\right)$-spiked isotope dilution thermal ionization mass spectrometric data. Geochemistry Geophysics Geosystems, 8: 1-20.

Schulmann, K., Gayer, R., 2000. A model for a continental accretionary wedge developed by oblique collision: the NE Bohemian Massif. Journal of the Geological Society, 157: 401-416.

Schulmann, K., Konopásek, J., Janoušek, V., Lexa, O., Lardeaux, J-M., Edel, J-B., Štípská, P., Ulrych, S., 2009. An Andean type Palaeozoic convergence in the Bohemian Massif. Comptes Rendus Geoscience, 341: 266-286.

Sivek, M., Dopita, M., Krůl, M., Čáslavský, M., Jirásek, J., 2003. Atlas of Chemical-Technological Properties of Coals in the Czech Part of the Upper Silesian Basin. Vysoká škola báňská TU Ostrava, Ostrava.

Skoček, V., 1989. Indications of Early Carboniferous events in Palaeozoic sequences of Moravia, Czechoslovakia. Časopis pro mineralogii a geologii, 34: 373-384

Stacey, J.S., Kramers, J.D., 1975. Approximation of terrestrial lead isotope evolution by a 2-stage model. Earth and Planetary Science Letters, 26: 207-221.

Steiger, R.H., Jäger, E., 1977. Subcommission on geochronology: Convention on the use of decay constants in geo- and cosmochronology. Earth and Planetary Science Letters, 36: 359-362.

Suchy, V., Frey, M., Wolf, M., 1997. Vitrinite reflectance and shear-induced graphitization in orogenic belts: a case study from the Kandersteg area, Helvetic Alps, Switzerland. International Journal of Coal Geology, 34: 1-20.

Suchý, V., Sýkorová, I., Melka, K., Filip, J., Machovič, V., 2007. Illite "crystallinity", maturation of organic matter and microstructural development associated with lowest-grade metamorphism of Neoproterozoic seiments in the TepláBarrandian unit, Czech Republic. Clay Minerals, 42: 415-438.

Trzepierczyńska, A., 2003. Palynostratigraphy of the Culm deposits of the Moravian-Silesian zone (Poland) at Toszek Castle Hill. Geological Quarterly, 47 (4): 373-380.

Unrug, R., 1966. L'évolution sédimentaire et tectonique du bassin hercynien de Moravie - Haute-Silésie. Bulletin de la Société Géologique de France, 7: 537-547.

Unrug, R., Dembowski, Z., 1971. Diastrophic and sedimentary evolution of the Moravia-Silesia Basin (in Polish with English summary). Rocznik Polskiego Towarzystwa Geologicznego, 41: 118-168.

Weyer, D., Menning, M., 2006. Geologische Zeitskala stratigraphische Nomenklatur und Magnetostratigraphie. In: Stratigraphie von Deutschland VI: Unterkarbon (Mississippium) (eds. R.W. Amler and D. Stoppel): 27-50. Deutsche Gesellschaft für Geowissenschaften, Hannover.

Zapletal, J., Dvořák, J., Kumpera, O., 1989. Stratigrafická klasifikace kulmu Nízkého Jeseníku (in Czech). Věsttník Ústředního ústavu geolologického, 64: 243-250.

Zimák, J., Losos, Z., Novotný, P., Dobeš, P., Hladíková, J., 2002. Study of vein carbonates and notes to the genesis of the hydrothermal mineralization in the Moravo-Silesian Culm. Journal of the Czech Geological Society, 47: 111-122. 